\title{
Evaluating Semiaquatic Herbaceous Perennials for Use in Herbicide Phytoremediation
}

\author{
R. Thomas Fernandez, Ted Whitwell, Melissa B. Riley, ${ }^{1}$ and Cassandra R. Bernard \\ Department of Horticulture, Clemson University, Clemson, SC 29634
}

\begin{abstract}
AdDitional INDEX words. chlorophyll fluorescence, $\mathrm{CO}_{2}$ assimilation, gas exchange, herbicide tolerance, isoxaben, photosynthesis, oryzalin
\end{abstract}

\begin{abstract}
Canna $\times$ generalis L.H. Bail. (canna), Pontaderia cordata L. (pickerel weed), and Iris L. $x$ 'Charjoys Jan' ('Charjoys Jan' iris) were exposed to a $5 \mathrm{mg} \cdot \mathrm{L}^{-1}$ suspension of isoxaben or oryzalin or a water control for 9 days. Growth and photosynthetic responses were monitored throughout treatment and for an additional $22 \mathrm{~d}$ after termination of treatment. By the end of the experiment plant height of pickerel weed was reduced by oryzalin. Isoxaben resulted in lower height and reduced leaf emergence for all three taxa by the end of the experiment. $\mathrm{Leaf}^{\mathrm{CO}_{2}}$ assimilation (A) and transpiration $(E)$ were lower for oryzalin-treated canna only 17 and 18 days after treatment, several days after treatment had been terminated. Leaf $A$ and $E$ were lower for oryzalin-treated pickerel weed and 'Charjoys Jan' iris for most days after day 17. Isoxaben reduced $A$ and $E$ of all three plants for all days measured except day 6 for 'Charjoys Jan' iris. Lower photosystem II efficiency (Fv/Fm) was found for isoxaben-treated canna from day 5 onward and days 7, 20, and 23 for pickerel weed and 'Charjoys Jan' iris. Rapid reduction in A and Fv/Fm for all plants treated with isoxaben indicates a direct effect of isoxaben on photosynthesis. Reductions in growth and photosynthetic parameters due to oryzalin were minimal for all plants indicating these plants would be useful in phytoremediation systems where oryzalin is present. However, growth and photosynthetic parameters were reduced substantially for all plants exposed to isoxaben indicating the taxa studied would not perform well in phytoremediation systems with this level of isoxaben exposure. Chemical names used: isoxaben ( $N$-[3-(1-ethyl-1-methylpropyl)-5-isoxazolyly]-2,6-dimethoxybenzamide); oryzalin (4(dipropylamino)-3,5-dinitrobenzenesulforamide).
\end{abstract}

Container nursery managers routinely apply three or more applications of granular preemergence herbicides to prevent weeds from becoming established. Depending on container spacing, up to $80 \%$ of an applied granular pesticide misses the target and falls directly onto the production surface (Gilliam et al., 1992). During spring and summer, herbicide applications are made $\approx 70$ to $90 \mathrm{~d}$ apart, preventing weed emergence but resulting in herbicide movement in runoff waters. Additionally, nonselective and preemergence herbicides are applied around containers to control emerged weeds to prevent them from producing seeds and infesting containers. Overhead irrigation creates runoff water resulting in transport of herbicides to containment ponds and/or offsite before they undergo degradation or are bound to soil or other substrates.

At container nurseries in South Carolina, detectable levels of pendimethalin (N-(1-ethylpropyl)-3,4-dimethyl-2,6-dinitrobenzenamine), oxyfluorfen (2-chloro-1-(3-ethoxy-4nitrophenoxy)-4-(trifluoromethyl) benzene) and oryzalin were found in the water and sediments of containment basins (Camper et al., 1994; Riley et al., 1994). Pesticides $>10 \mathrm{mg} \cdot \mathrm{L}^{-1}$ have been detected in nursery runoff water and in nursery retention basins used for recycled irrigation (Keese et al., 1994; Wilson et al., 1996). Residual amounts of herbicides can be beneficial as minute traces will control sensitive weeds (Skimina, 1992). However, phytotoxicity problems can result when sensitive nursery crops are irrigated with recycled water containing herbicide residues or when one herbicide is used extensively (Bhandary et al., 1997a; Skimina, 1992). Oryzalin, oxyfluorfen and isoxaben

Received for publication 9 Dec. 1998. Accepted for publication 21 June 1999. Support for this research was provided by the Ornamental Enhancement Program of the South Carolina Agricultural Experiment Station. South Carolina Agricultural Experiment Station technical contribution 4477. The cost of publishing this paper was defrayed in part by the payment of page charges. Under postal regulations, this paper therefore must be hereby marked advertisement solely to indicate this fact.

${ }^{1}$ Department of Plant Pathology and Physiology. caused reduced growth of daylily (Hemerocallis L.) and fountain grass (Pennisetum rupelli Steudel) at concentrations of 1 and 10 $\mathrm{mg} \cdot \mathrm{L}^{-1}$ and root damage to Japanese holly (Ilex crenata Thunb.) at $10 \mathrm{mg} \cdot \mathrm{L}^{-1}$ (Bhandary et al., 1997a). Concerns for protection of water resources and the detrimental reintroduction of pollutants onto the crop through recycling of waters necessitate use of techniques to reduce movement and enhance remediation of agricultural chemicals in runoff waters.

Vegetative filter strips (VFS) are used extensively in treatment of municipal waste waters and runoff waters from pulp mills and livestock feed lots. Defined as vegetated areas which receive and purify runoff from an up-slope pollutant source (Chaubey et al., 1994), VFS are a low cost, estimated at $\$ 93$ per tonne of abated sediment, and practical option for improving the quality of runoff water (Pritchard et al., 1993). Grasses and semiaquatic plants are efficacious removers of nutrients and sediments from runoff water (Dillaha et al., 1989; Thut, 1990; Wolverton et al., 1983). Vegetative filter strips reduce transport capacity and sediment movement of runoff waters by reducing flow and allowing time for plant uptake or infiltration of pollutants into soils and subsequent degradation before entering water systems. Effectiveness is based upon the flow depth and velocity of the runoff water, vegetation density, incoming sediment and pollutant loads, and size and slope of the VFS (Dillaha et al., 1989). Vegetative filter strips have reduced herbicide and fungicide concentrations in nursery runoff water (Briggs et al., 1998).

Herbicide contamination of nursery runoff water is becoming a major concern for the nursery industry. With increased environmental concern, the industry must find an effective and economical method of water decontamination. Phytoremediation is one such method for removing pollutants from runoff (Pritchard et al., 1993; Shimp et al., 1993). Although VFS have been used to filter herbicides and other contaminants effectively, land that would be used for remediation would be lost to production. Aquatic plants in a nursery environment have been evaluated for use in mitigating nutrient levels from catfish production ponds (Bilderback et 
Table 1. Growth response of Canna $\times$ generalis, Pontaderia cordata, and Iris $\mathrm{x}$ 'Charjoys Jan' to oryzalin or isoxaben. Plants were treated every other day for the first $8 \mathrm{~d}$ with $1 \mathrm{~L}$ of $5 \mathrm{mg} \cdot \mathrm{L}^{-1}$ oryzalin or isoxaben solution or a water control beginning 26 May 1998.

\begin{tabular}{|c|c|c|c|c|c|c|c|c|c|}
\hline \multirow[b]{3}{*}{ Treatment } & \multicolumn{9}{|c|}{ Days after treatment } \\
\hline & \multicolumn{3}{|c|}{$-1^{2}$} & \multicolumn{3}{|c|}{9} & \multicolumn{3}{|c|}{3} \\
\hline & $\begin{array}{c}\text { Leaf } \\
\text { emergence }\end{array}$ & $\begin{array}{l}\mathrm{Ht} \\
(\mathrm{cm})\end{array}$ & $\begin{array}{l}\text { Width } \\
(\mathrm{cm})\end{array}$ & $\begin{array}{c}\text { Leaf } \\
\text { emergence }\end{array}$ & $\begin{array}{l}\mathrm{Ht} \\
(\mathrm{cm})\end{array}$ & $\begin{array}{l}\text { Width } \\
\text { (cm) }\end{array}$ & $\begin{array}{c}\text { Leaf } \\
\text { emergence }\end{array}$ & $\begin{array}{l}\mathrm{Ht} \\
(\mathrm{cm})\end{array}$ & $\begin{array}{l}\text { Width } \\
\text { (cm) }\end{array}$ \\
\hline & \multicolumn{9}{|c|}{ Canna $\times$ generalis } \\
\hline Control & 0 & $50.8 \mathrm{a}$ & $56.3 \mathrm{a}$ & $2 \mathrm{a}$ & $49.5 \mathrm{a}$ & $53.8 \mathrm{a}$ & $2 \mathrm{a}$ & $57.2 \mathrm{a}^{\mathrm{y}}$ & $53.3 \mathrm{a}$ \\
\hline Oryzalin & 0 & $52.1 \mathrm{a}$ & $53.3 \mathrm{a}$ & $1 \mathrm{a}$ & $51.4 \mathrm{a}$ & $54.4 \mathrm{a}$ & $2 \mathrm{a}$ & $48.0 \mathrm{a}$ & $52.2 \mathrm{a}$ \\
\hline \multirow[t]{2}{*}{ Isoxaben } & 0 & $46.9 \mathrm{a}$ & $50.7 \mathrm{a}$ & $1 \mathrm{a}$ & $49.7 \mathrm{a}$ & $48.3 \mathrm{a}$ & $-1 b^{x}$ & $30.6 \mathrm{~b}$ & $31.0 \mathrm{~b}$ \\
\hline & \multicolumn{9}{|c|}{ Pontaderia cordata } \\
\hline Control & 0 & $37.0 \mathrm{a}$ & --- & $4 \mathrm{a}$ & $36.6 \mathrm{a}$ & --- & $14 \mathrm{a}$ & $43.3 \mathrm{a}$ & --- \\
\hline Oryzalin & 0 & $36.8 \mathrm{a}$ & --- & $5 \mathrm{a}$ & $35.1 \mathrm{a}$ & --- & $19 \mathrm{a}$ & $31.4 \mathrm{~b}$ & --- \\
\hline Isoxaben & 0 & $36.2 \mathrm{a}$ & --- & $2 \mathrm{~b}$ & $35.4 \mathrm{a}$ & --- & $0 b^{y}$ & $23.1 \mathrm{c}$ & --- \\
\hline & \multicolumn{9}{|c|}{ Iris $\mathrm{x}$ 'Charjoys Jan’ } \\
\hline Control & 0 & $61.2 \mathrm{a}$ & --- & $3 a$ & $61.8 \mathrm{a}$ & --- & $5 a$ & $48.2 \mathrm{a}$ & --- \\
\hline Oryzalin & 0 & $63.1 \mathrm{a}$ & --- & $2 a$ & $62.8 \mathrm{a}$ & --- & $3 a$ & $46.6 \mathrm{a}$ & --- \\
\hline Isoxaben & 0 & $65.6 \mathrm{a}$ & --- & $2 \mathrm{a}$ & $63.8 \mathrm{a}$ & --- & $-3 b^{y}$ & $23.3 \mathrm{~b}$ & --- \\
\hline
\end{tabular}

${ }^{\mathrm{Z}}$ Data recorded $1 \mathrm{~d}$ before initiation of treatments. Leaf emergence determined from this date.

'Means followed by different letters within species and column are significantly different at $P=0.05$ by Tukey's HSD.

${ }^{x}$ Total average leaf loss from maximum 2.5 and 5.1 for Canna and Iris, respectively.

al., 1993). A similar technique is envisioned for remediation of runoff water from nursery beds, where runoff is channeled through retention areas with container-grown, semiaquatic plants for remediation of nutrients and pesticides as well as production of these plants for future sale. Use of a remediation area as a crop production area would prove profitable to nurseries and could be effective in removing contaminants. However, response of commercially viable ornamental species to conditions likely to be encountered in such situations, especially herbicide tolerance, has not been determined. Therefore, the objectives of this study were to determine the response of three ornamental semiaquatic plants to two commonly used herbicides at levels likely to be encountered in such a phytoremediation area.

\section{Materials and Methods}

This research was conducted in a polyethylene greenhouse at the South Carolina Botanical Garden, Clemson University, Clemson, S.C. Plant response to two common preemergent herbicides, isoxaben and oryzalin, were evaluated in this study. The commercial formulation used for isoxaben was Gallery and for oryzalin was Surflan (Dow AgroSciences, Indianapolis, Ind.). Both of these preemergent herbicides are used commonly in nursery production (Neal and Senesac, 1990; Skroch et al., 1994). Three semiaquatic plants of commercial value, canna, pickerel weed, and 'Charjoys Jan' iris, were evaluated as potential phytoremediation candidates. Uniform rooted cuttings were potted in standard no. 1 nursery containers $(3.8 \mathrm{~L}$ volume) in a sand medium. Plant size $1 \mathrm{~d}$ before treatment is presented in Table 1 . The bottoms of the containers were covered with a woven polypropylene landscape fabric (WeedBlock Landscape Fabric, Waco, Texas) to prevent sand loss through the drainage holes. Two weeks before imposition of treatments, plants were fertilized to runoff with $250 \mathrm{mg} \cdot \mathrm{L}^{-1} \mathrm{~N}$ from a $20 \mathrm{~N}-8.6 \mathrm{P}-16.6 \mathrm{~K}$ water soluble fertilizer (Scotts-Sierra, Marysville, Ohio).

In a runoff study conducted at an ornamental container nursery, Keese et al. (1994) found oryzalin residues of $4 \mathrm{mg} \cdot \mathrm{L}^{-1} 15 \mathrm{~min}$ after runoff began on the day of application. In another study, isoxaben residues were found at $3.26 \mathrm{mg} \cdot \mathrm{L}^{-1}$ within the first 20 min of runoff on the day of application (Briggs, 1996). To determine plant response to the highest expected exposure levels based on these studies, containers were placed in 4.75-L plastic buckets (Leaktite, Leominster, Mass.) to create a treatment reservoir and plants were treated with $1 \mathrm{~L}$ of a $5 \mathrm{mg} \cdot \mathrm{L}^{-1}$ suspension of isoxaben or oryzalin or a water control. Treatments were imposed 26 May through 4 June 1998. Treatment suspensions or water were applied to the reservoir buckets every second day over $9 \mathrm{~d}$ for a total of five treatments. The buckets were wrapped in aluminum foil to decrease herbicide photodegradation. The height of the buckets was equal to the height of the container. There were 15 replications per treatment per species for a total of 135 plants. The plants were arranged in a completely randomized design. Plants were grown in this system beginning 26 to 28 Apr. 1998 until implementation of the treatments $\approx 1$ month later. During this time water was supplied to maintain about a $4 \mathrm{~cm}$ water reservoir in the buckets so that plants would acclimate to saturated water conditions. Since herbicides can degrade or be taken up and metabolized by plants, treatments were replaced every other day to maintain a high concentration. Liquid remaining from the previous application was discarded before treating again. After termination of treatments, all plants were watered as they were before imposition of treatments.

Plant performance during treatments and recovery from treatments was determined by measuring growth, leaf gas exchange, and chlorophyll fluorescence. Leaf $\mathrm{CO}_{2}$ assimilation (A) and transpiration (E) were measured 3 to $5 \mathrm{~d}$ apart as weather permitted throughout the experiment using a portable infrared gas analyzer (CIRAS-1, PP Systems, Haverhill, Mass.) with a Parkinson broadleaf chamber (CIRAS-1 Parkinson leaf cuvette, PP Systems, Haverhill, Mass.). One recently mature, fully expanded leaf per plant was measured beginning at $\approx 1000 \mathrm{HR}$ for $\mathrm{A}$ and E. Photosynthetically active radiation $(P A R)$ and air temperature were measured at the same time as leaf gas exchange with a silica quantum sensor and precision thermistor attached to the leaf cuvette. Chlorophyll fluorescence was measured on the same type of leaf using a modulated fluorometer (model OS-500, Opti- 

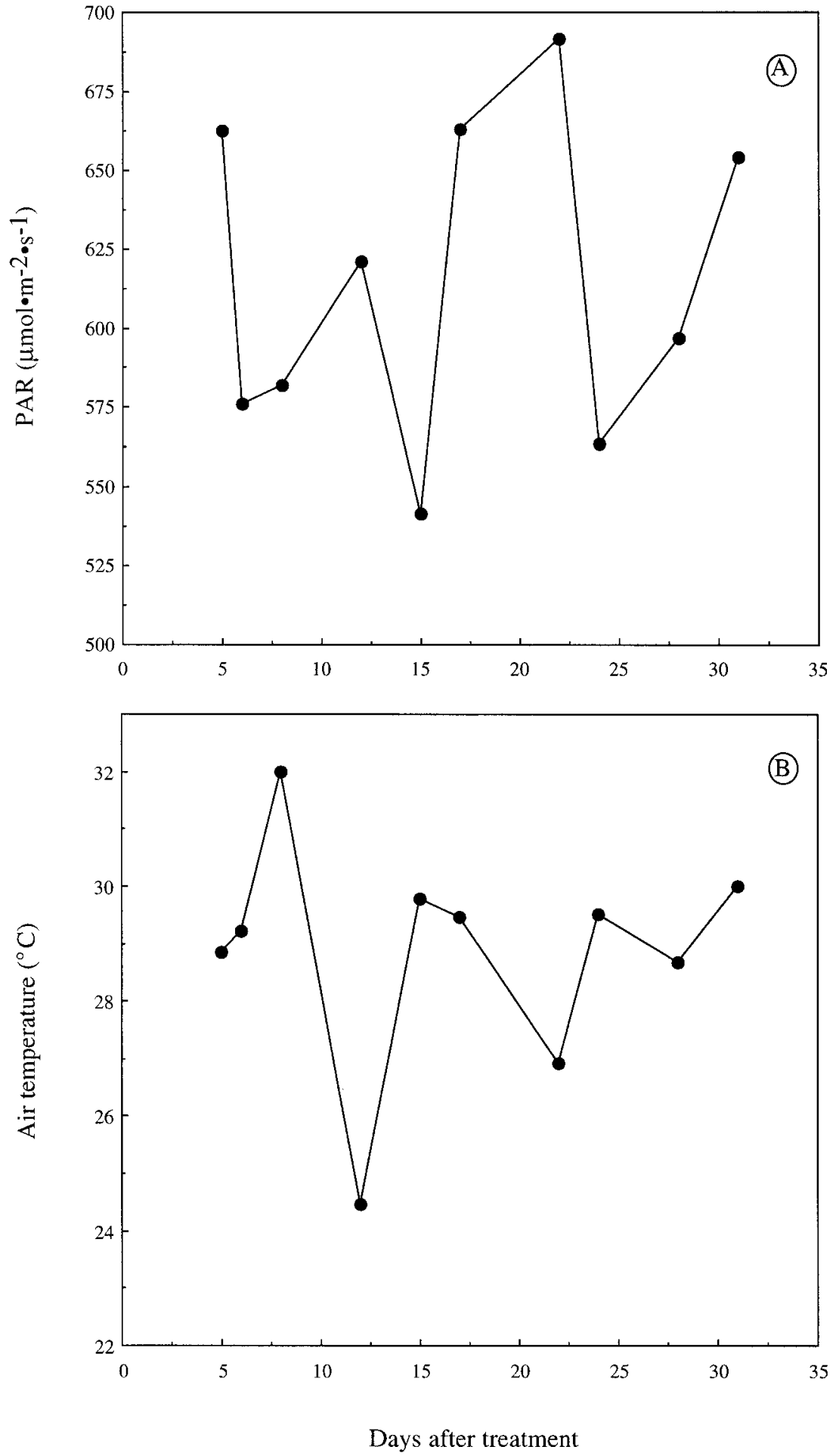

separation for leaf gas exchange and chlorophyll fluorescence was by repeated measures in time and for growth by Tukey's HSD.

\section{Results and Discussion}

Average $P A R$ and air temperature during measurement of $A$ and $E$ provided conditions that were not restrictive of $\mathrm{A}$ and $\mathrm{E}$ (Fig. 1). The greatest reductions in A were seen for isoxaben-treated plants compared to control and oryzalin-treated plants (Fig. 2). There was a reduction in A for plants exposed to isoxaben compared to controls from the first measurement, day 5, throughout the remainder of the experiment for canna (Fig. 2A) and pickerel weed (Fig. 2B) and from day 6 throughout the remainder of the experiment for 'Charjoys Jan' iris (Fig. 2C). Assimilation was close to zero for isoxaben-treated canna and 'Charjoys Jan' iris for most measurements after day 5 and below zero on three of the days measured, reflecting greater respiratory loss of carbon than gain. Reductions in A due to oryzalin were seen for canna on days 15 and 17 only (Fig. 2A). Lower A was found for oryzalintreated pickerel weed and 'Charjoys Jan' iris from day 17 throughout the experiment except for day 28 and 24, respectively (Fig. 2B and 2C). Additionally, plants exposed to oryzalin usually had higher $\mathrm{A}$ than those exposed to isoxaben.

Lower $\mathrm{E}$ was seen for all measurements of isoxaben-treated canna (Fig. 3A) and all except day 5 of isoxaben-treated pickerel weed (Fig. 3B) and 'Charjoys Jan' iris (Fig. 3C). Oryzalin also reduced $\mathrm{E}$ on days 15 and 17 for canna (Fig. 3A) and from day 12 and 8 onward for pickerel weed (Fig. 3B) and 'Charjoys Jan' iris (Fig. 3C), respectively, except on day 28 for pickerel weed and day 24 for 'Charjoys Jan' iris.

During water stress, E often is affected before A due to reduced water availability (Fernandez et al., 1997; Raschke, 1979). In this study, transpiration was reduced earlier and more frequently than $\mathrm{A}$ for oryzalin-treated plants indicating the initial response could be caused by root system injury resulting in reduced water transport. Reductions in $\mathrm{E}$ and $\mathrm{A}$ occurred early in the experiment within $1 \mathrm{~d}$ of each other for isoxaben-treated plants. This suggests some factor other than water transport is responsible for reduced $\mathrm{A}$ in isoxaben-treated plants.

Efficiency of photosystem II (PS II) is reflected in the ratio of variable fluorescence $(\mathrm{Fv})$ to maximal

Fig. 1. (A) Photosynthetically active radiation $(P A R)$ and (B) air temperature during measurement of leaf gas exchange. Each symbol represents the mean of 90 measurements.

Sciences, Inc., Tyngsboro, Mass.) on days 1, 3, 5, 7, 20, and 23 on leaves that had been dark acclimated for a minimum of $10 \mathrm{~min}$. Plant heights, widths (canna only), and number of expanded leaves were measured $1 \mathrm{~d}$ before initial treatment, immediately following termination of treatment (day 8) and on day 31 .

Data were subjected to analysis of variance using the PROC GLM procedure of SAS (SAS Inst., Inc., Cary, N.C). Mean fluorescence $(\mathrm{Fm})(\mathrm{Fv} / \mathrm{Fm})$. Lower Fv/Fm was found for isoxabentreated canna from day 5 onward and on days 7, 20, and 23 for pickerel weed and 'Charjoys Jan' iris (Fig. 4). Oryzalin reduced $\mathrm{Fv} / \mathrm{Fm}$ only for day 7 of 'Charjoys Jan' iris. Reductions in Fv/Fm occurred close to the same time as reductions in A for isoxabentreated plants. Chlorophyll fluorescence is not considered especially sensitive to water stress and usually is affected only after severe water stress (Fernandez et al., 1997; Karukstis, 1991; Krause and Weiss, 1984). Isoxaben is translocated quickly to leaves (Cabanne et al., 1987) and early reductions in chlorophyll fluorescence for canna and A for isoxaben treatments indicate a 

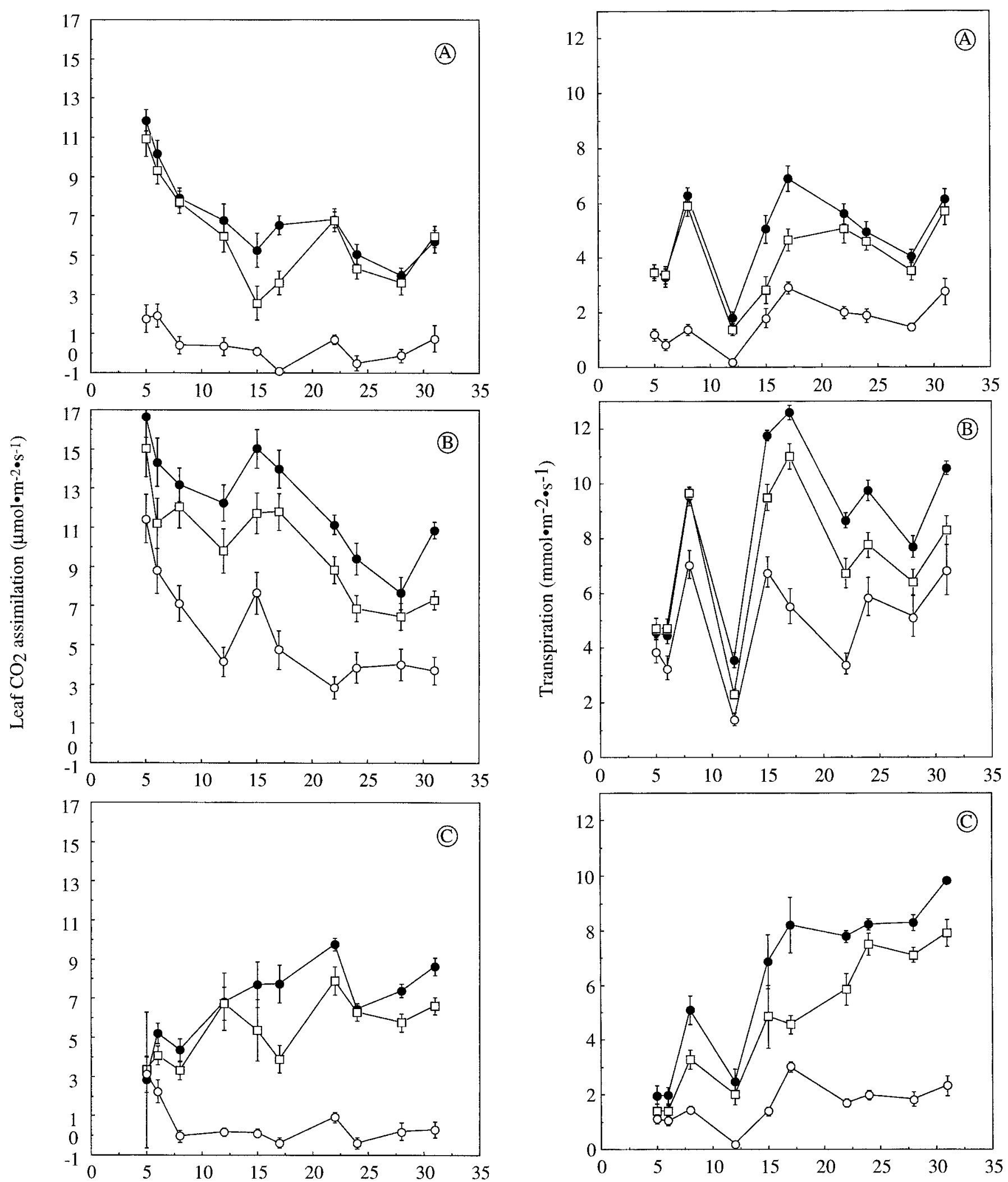

Days after treatment

Fig. 2. Leaf $\mathrm{CO}_{2}$ assimilation for (A) Canna $\times$ generalis, (B) Pontaderia cordata, and (C) Iris X 'Charjoys Jan' for control $(\mathbf{O})$ and plants treated for the first $9 \mathrm{~d}$ with $5 \mathrm{mg} \cdot \mathrm{L}^{-1}$ oryzalin $(\square)$ or isoxaben $(\bigcirc)$. Each symbol represents the mean of 10 plants $\pm \mathrm{SE}$. 

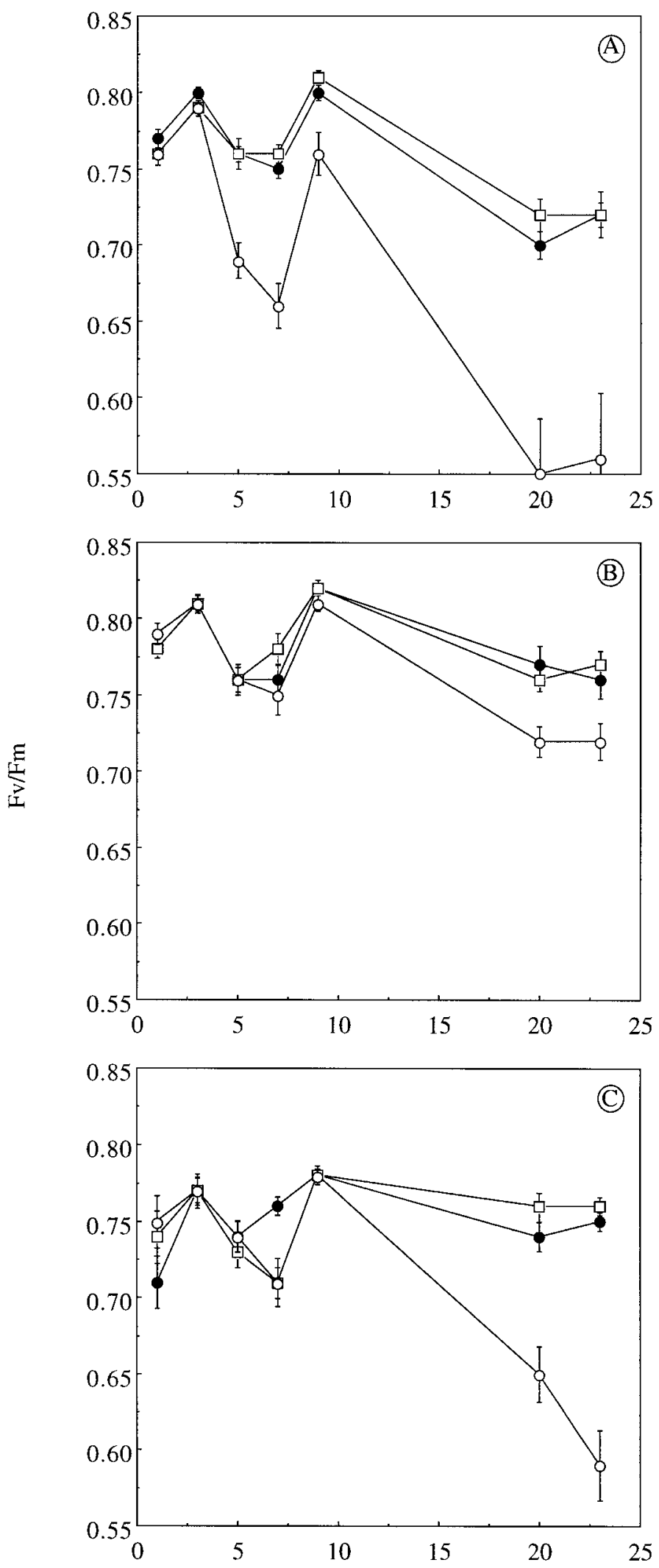

Days after treatment

Fig. 4. Photosystem II efficiency (Fv/Fm) of (A) Canna $\times$ generalis, (B) Pontaderia cordata, and (C) Iris X 'Charjoys Jan' for control $(\mathbf{O})$ and plants treated for the first $9 \mathrm{~d}$ with $5 \mathrm{mg} \cdot \mathrm{L}^{-1}$ oryzalin $(\square)$ or isoxaben $(\bigcirc)$. Each symbol represents the mean of 10 plants \pm SE. direct effect of the herbicide on photosynthesis rather than changes in water relations caused by damage to the root system.

Dinitroaniline herbicides, such as oryzalin, reduced A and inhibited photophosphorylation (Bhandary et al., 1997b; Moreland et al., 1972a, 1972b). Twelve dinitroaniline herbicides were used in studies by Moreland (1972a, 1972b) and oryzalin caused the greatest reduction of A. Inhibition of photophosphorylation results in further reduction of A by reducing ATP availability. In a study to simulate contaminated irrigation water, A was reduced at 2 and 4 weeks when irrigated daily for 6 weeks with water containing 1 $\mathrm{mg} \cdot \mathrm{L}^{-1}$ oryzalin although 0.1 or $0.01 \mathrm{mg} \cdot \mathrm{L}^{-1}$ oryzalin had no effect (Bhandary et al., 1997b). However, dinitroanilies are not readily translocated in plants (Probst et al., 1975). In this study, reductions in $\mathrm{A}$ and $\mathrm{E}$ for oryzalin-treated plants occurred much later than for isoxaben-treated plants and could be due either to changes in water relations caused by root damage or accumulation of damaging levels of oryzalin. Although oryzalin is not translocated readily, when using contaminated reclaimed water for overhead irrigation, there is the possibility of absorption by leaves.

The only differences in growth for any of the plants treated with oryzalin was lower plant height of pickerel weed on day 31 (Table 1). However, isoxaben caused reduced leaf emergence on days 9 and 31 for pickerel weed and reduced leaf emergence and plant height (and width for canna) on day 31 for all three species. There was an overall loss of leaves by day 31 for isoxaben-treated plants from the initial measurement for canna and 'Charjoys Jan' iris, with a minor gain for pickerel weed, but all species showed a loss of leaves between the first two measurements.

Isoxaben inhibits synthesis of acid insoluble cell wall materials in seedlings (Heim et al., 1990). Oryzalin affects mitosis by inhibiting microtubule formation (Strachan and Hess, 1983). The combination of lower A, even to the point of greater respiration than assimilation, loss of leaves, and the effects of the herbicides on cell wall biosynthesis or mitosis would explain the reductions seen in plant growth primarily for isoxaben-treated plants.

In a phytoremediation system where runoff from nursery production beds is channeled through a reservoir that is being used to produce semiaquatic plants, canna shows good potential as a phytoremediating plant for oryzalin as indicated by the few reductions in A, E, chlorophyll fluorescence, and growth. Pickerel weed and 'Charjoys Jan' iris showed more frequent reductions in $\mathrm{A}$ and $\mathrm{E}$ when exposed to oryzalin but only minor differences in growth and also may be useful as oryzalin phytoremediators. At the levels of isoxaben used in this study, none of the plants showed favorable results for use in phytoremediation. Other species may be less sensitive to isoxaben. Phytoremediation areas in nurseries likely will consist of a mixture of taxa that differ in sensitivity to various pesticides. Additional work is needed to aid in selection of plants that will tolerate conditions likely to occur in phytoremediation areas.

\section{Literature Cited}

Bhandary, R., T. Whitwell, and J. Briggs. 1997a. Growth of containerized landscape plants is influenced by herbicides residues in irrigation water. Weed Technol. 11:793-797

Bhandary, R., T. Whitwell, J. Briggs, and R.T. Fernandez. 1997b. Influence of Surflan (oryzalin) concentrations in irrigation water on growth and physiological processes of Gardenia jasminoides radicans and Pennisetum rupelli. J. Environ. Hort. 169-172.

Bilderback, T.E., M.A. Powell, T.M. Losordo, S.W. Broome, and S.H. Kay. 1993. An aquatic plant production and nutrient mitigation system. Southern Nurserymen's Assn. Res. Conf., 38th Annu. Rpt. p. 422-426. Briggs, J. 1996. Characterization and remediation of pesticides trans- 
ported in runoff water from a containerized plant nursery. MS thesis, Clemson Univ., Clemson, S.C.

Briggs, J.A., M.B. Riley, and T. Whitwell. 1998. Characterization and remediation of pesticides in runoff water from containerized plant production. J. Environ. Qual. 27:814-820.

Cabanne, R., A. Lefebvre, and R. Scalla. 1987. Behaviour of the herbicide EL-107 in wheat and rape grown under controlled conditions. Weed Res. 27:135-142.

Camper, N.D., T. Whitwell, R.J. Keese, and M.B. Riley. 1994. Herbicide levels in nursery containment pond water and sediments. J. Environ. Hort. 12:8-12.

Chaubey, I., D.R. Edwards, T.C. Daniel, P.A. Moore, Jr., and D.J. Nichols. 1994. Effectiveness of vegetative filter strips in retaining surface-applied swine manure constituents. Trans. Amer. Soc. Agr. Eng. 37:845-850.

Dillaha, T.A., R.B. Reneau, S. Mostaghimi, and D. Lee. 1989. Vegetative filter strips for agricultural nonpoint source pollution control. Trans. Amer. Soc. Agr. Eng. 32:513-519.

Fernandez, R.T., R.L. Perry, and J.A. Flore. 1997. Drought response of young apple trees on three rootstocks. II. Gas exchange, chlorophyll fluorescence, water relations, and leaf abscisic acid. J. Amer. Soc. Hort. Sci. 122:841-848.

Gilliam, C.H., D.C. Fare, and A. Beasley. 1992. Nontarget herbicide losses from application of granular ronstar to container nurseries. J. Environ. Hort. 10:175-176.

Heim, D.R., J.R. Skomp, E.E. Tschabold, and I.M. Larrinua. 1990. Isoxaben inhibits the synthesis of acid insoluble cell wall materials in Arabidopsis thaliana. Plant Physiol. 93:695-700.

Karukstis, K.K. 1991. Chlorophyll fluorescence as a physiological probe of the photosynthetic apparatus, p. 769-795. In: H. Sheer (ed.). Chlorophylls. CRC Press, Boca Raton, Fla.

Keese, R.J., N.D. Camper, T. Whitwell, M.B. Riley, and P.C. Wilson. 1994. Herbicide runoff from ornamental container nurseries. J. Environ. Qual. 23:320-324.

Krause, G.H. and E. Weiss. 1984. Chlorophyll fluorescence as a tool in plant physiology. II. Interpretation of fluorescence signals. Photosynthesis Res. 5:139-157.

Moreland, D.E., F.S. Farmer, and G.G. Hussey. 1972a. Inhibition of photosynthesis and respiration by substituted 2,6-dinitroaniline herbicides. I. Effects on chloroplast and mitochondrial activities. Pest.
Biochem. Physiol. 2:342-353

Moreland, D.E., F.S. Farmer, and G.G. Hussey. 1972b. Inhibition of photosynthesis and respiration by substituted 2,6-dinitroaniline herbicides. II. Effects on responses in excised plant tissues and treated seedlings. Pest. Biochem. Physiol. 2:342-353.

Neal, J.C. and A.F. Senesac. 1990. Summer annual and winter annual weed control in field soil and soilless media with Gallery (isoxaben). J. Environ. Hort. 8:124-127.

Pritchard, T.W., J.G. Lee, and B.A. Engel. 1993. Reducing agricultural sediment: An economic analysis of filter strips versus micro-targeting. Water Sci. Technol. 28:561-568.

Probst, G.W., T. Golab, and W.L. Wright. 1975. Dinitroanilines, p. 453500. In: P.C. Kearney and D.D. Kaufman (eds.). Herbicides: Chemistry, degradation, and mode of action. vol. I. Marcel Dekker, New York. Raschke, K. 1979. Movements of stomata, p. 383-441. In: W. Haupt and M.E. Feinleib (eds.). Encyclopedia of plant physiology. vol. 7. Physiology of movements. Springer-Verlag, Berlin.

Riley, M.B., R.J. Keese, N.D. Camper, T. Whitwell, and P.C. Wilson. 1994. Pendimethalin and oxyfluorfen residues in pond water and sediment from container plant nurseries. Weed Technol. 8:299-303.

Shimp, J.F., J.C. Tracy, L.C. Davis, E. Lee, W. Huang, and L.E. Erickson. 1993. Beneficial effects of plants in the remediation of soil and groundwater contaminated with organic materials. Crit. Rev. Environ. Sci. Technol. 23:41-77.

Skimina, C.A. 1992. Recycling water, nutrients, and waste in the nursery industry. HortScience 27:968-971.

Skroch, W.A., C.J. Catanzaro, A.A. DeHertogh, and L.B. Gallitano. 1994. Preemergence herbicide evaluations on selected spring and summer flowering bulbs and perennials. J. Environ. Hort. 12:80-82.

Strachan, S.D. and F.D. Hess. 1983. The biochemical mechanism of action of the dinitroaniline herbicide oryzalin. Pesticide Biochem. Physiol. 20:141-150.

Thut, R.N. 1990. Utilization of artificial marshes for treatment of pulp mill effluent. Tech. Assn. Pulp Paper Ind. J. 73:93-96.

Wilson, C., T. Whitwell, and M.B. Riley. 1996. Detection and dissipation of isoxaben and trifluralin in containerized plant nursery runoff water. Weed Sci. 44:683-688.

Wolverton, B.C., R.C. McDonald, and W.R. Duffer. 1983. Microorganisms and higher plants for waste water treatment. J. Environ. Qual. $12: 236-242$. 